
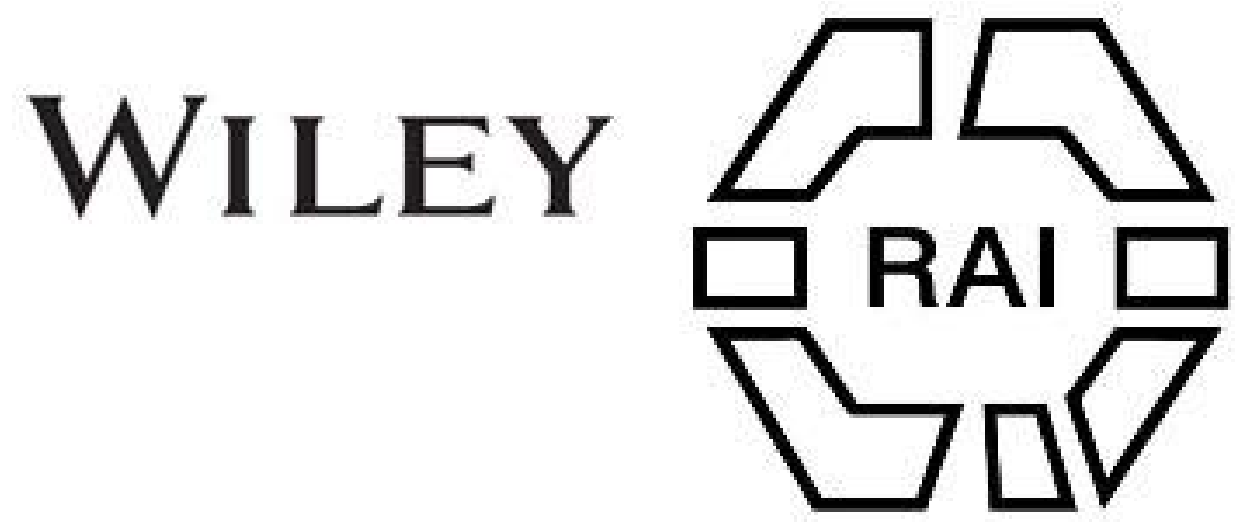

\title{
103. Polynesian Forgeries
}

\section{Author(s): W. O. Oldman}

Source: Man, Vol. 10 (1910), p. 188

Published by: Royal Anthropological Institute of Great Britain and Ireland

Stable URL: http://www.jstor.org/stable/2788787

Accessed: 26-06-2016 11:52 UTC

Your use of the JSTOR archive indicates your acceptance of the Terms \& Conditions of Use, available at

http://about.jstor.org/terms

JSTOR is a not-for-profit service that helps scholars, researchers, and students discover, use, and build upon a wide range of content in a trusted digital archive. We use information technology and tools to increase productivity and facilitate new forms of scholarship. For more information about JSTOR, please contact support@jstor.org.

Wiley, Royal Anthropological Institute of Great Britain and Ireland are collaborating with JSTOR to digitize, preserve and extend access to Man 
The cave is thus clearly shown by its fauna and the uniform type of implement to be of the Mousterien period, and thus forms an interesting addition, not only to the archæology of Jersey, but to that of Europe at large.

ED. TOULMIN NICOLLE. J. SINEL.

Polynesia.

Oldman.

Polynesian Forgeries. By $W$. O. Oldman.

Having read the valuable articles by Mr. J. Edge-Partington in MaN 0

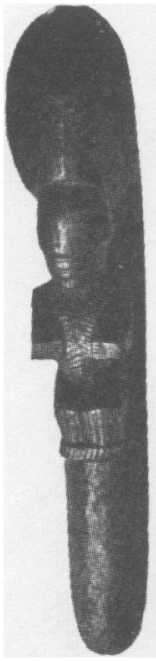

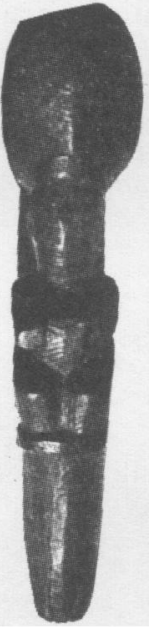

FIG. 1 .

(31, 1910), on Maori forgeries, I venture to think the following may be a welcome addition to same.

I have lately had offered to me several splendidly made copies of Maori flutes, the workmanship on which was so excellent that it would deceive anyone familiar with old Maori work ; the wood, method of manufacture (rending of wood), carving, bindings, \&c., were all quite correct, even to a deposit of dust inside; however, all were wanting in one small detail, which was overlooked by the maker.

I have also seen a carved bone coinb, feeding funnel, so-called chief's staff of remarkable form, and several "Hawaiian" bone fishhooks. The latest pro duction of this " artist," as far as I know, is a pair of "Marquesan" stilt steps. I have fortunately been able to secure two photographs of these, showing the original from which they were undoubtedly copied, which I send herewith. The work and finish on these is so good that they would be very likely to deceive even an expert, at any rate at first sight.

I trust this short note will be of some use as a warning to collectors of

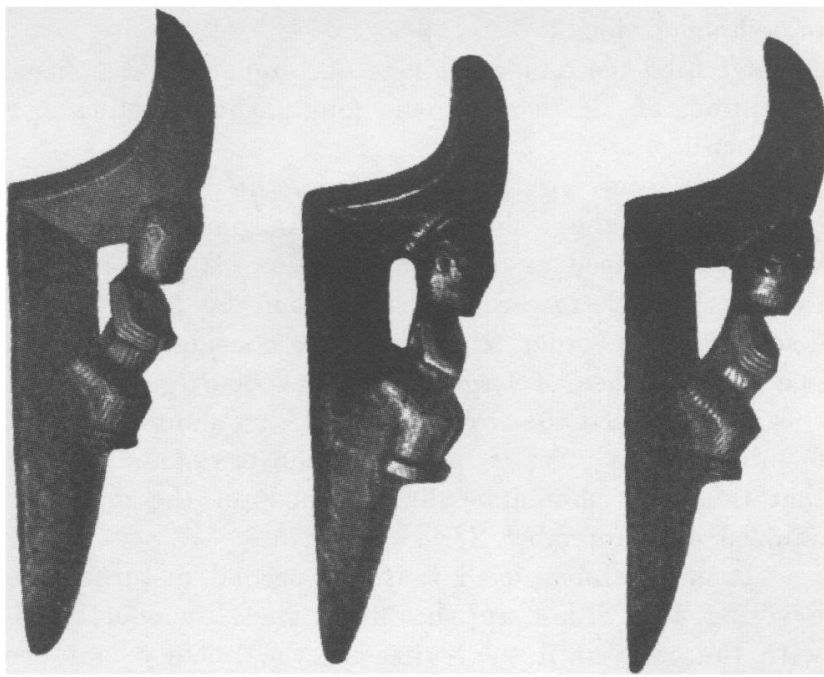

FIG. 2.

ethnographica to look very carefully at any rare objects offered for sale ; I bope also that it will lead ultimately to a stop being put to these dangerous reproductions.

W. O. OLDMAN. 